\title{
GERAKAN AMAL TROUPE PADA RELAWAN (SR) SEDEKAH ROMBONGAN
}

\author{
Dhaniar Ratih Rahmawati \\ Pascasarjana Universitas Islam Negeri Sunan Kalijaga Yogjakarta \\ ratihdhaniar@gmail.com \\ Muhammad Nur \\ Pascasarjana Universitas Islam Negeri Sunan Kalijaga Yogjakarta \\ noermoehammad94@gmail.com
}

\begin{abstract}
This research is about philanthropic practices conducted by volunteers (SR) Alms Group, one of the charitable organizations engaged in social care. This organization is based on organizations related to Muslim religions, this organization is intended to bring together donors without a neat organizational system and has only less than ten members involved and moves reactively on the road, but the structure of rational transitions is fast. The study was conducted field observations with interviews with SR volunteers who were in Yogyakarta, the authors wanted to know the motives for encouraging volunteers to work in SR charities, and also wanted to find out how to improve the performance of SRs through either instrumental or reactive or spontaneity. The results of this study prove that SR volunteers Get inspiration from their religious ethos that motivates them to work with charity motorcycles in SR, and have a perspective related to others will be transactional, have reciprocity for those who own it. While spontaneous work actions are their way of not making it difficult for people who need help belping is action and also by working through instrumental action because the intended purpose is to eradicate the poor who are oppressed due to economic, health factors, all of which cannot be done through spontaneous giving .
\end{abstract}

Keywords: Philanthropy, Charity, Ethos of Religion, SR

\begin{abstract}
Abstrak
Penelitian ini tentang praktek filantropi yang dilakukan oleh relawan (SR) Sedekah Rombongan, salah satu organisasi amal kemanusiaan yang bergerak di bidang kepedulian sosial. Organisasi ini bukanlah organisasi yang berbasis keagamaan namun hampir semua relawan adalah muslim, organisasi ini awalnya merupakan wadah untuk menghimpun donatur tanpa sistem organisasi yang rapi dan hanya memiliki kurang dari sepuluh anggota di dalamnya dan bergerak secara reaksional di jalanan, namun dalam dinamikanya organisasi ini mulai masuk dalam struktur mekanisme rasional. Penelitian ini menggunakan metode penelitian deskriptif kualitatif yang berusaha menemukan karakteristik secara mendalam terhadap subyek penelitian yakni dengan melakukan observasi dan wawancara terhadap para relawan SR yang berada di Kota Yogyakarta, penulis ingin mengetahui motif dorongan gerakan para relawan dalam bekerja di lembaga amal SR, dan juga ingin mengetahui bagaimana kinerja yang dilakukan oleh SR baik melalui mekanisme instrumental maupun reaksional atau spontanitas. Hasil dari penelitian ini menggambarkan bahwa para relawan SR mayoritas memiliki inspirasi dari etos agamanya yang memotivasi mereka dalam bekerja menjadi motor gerakan amal di SR, dan memiliki perspektif bahwa peduli terhadap sesama akan bernilai transaksional yakni memiliki timbal balik kepada dirinya sendiri. Sedangkan prosedur kerja secara reaksional spontan merupakan cara mereka untuk tidak mempersulit
\end{abstract}


bagi yang sangat membutuhkan bantuan karena menolong adalah aksi dan juga dengan cara kerja melalui tindakan rasional instrumental karena sasaran utamanya ialah mengentaskan kaum dhuafa yang tertindas karena faktor ekonomi maupun kesehatan, yang kesemuanya tidak bisa dilakukan melalui pemberian secara spontan.

Kata Kunci: Filantropi, Amal, Etos Agama, SR

\section{Pendahuluan}

Membingkai tindakan memberi kepada yang membutuhkan merupakan sebuah tindakan yang sejalan etika teologis atau dalam Max Weber disebut sebagai memberi (sedekah) adalah aspek dari etika agama, sebagaimana Marcel Mauss juga mengatakan bahwa pemberian tidak akan pernah lenyap, banyak volunter yang membingkai tindakan memberi sebagai sebuah kewajiban dan tidak jarang yang menganggap sebagai relasi transaksional yang bisa berupa imbalan di akhirat. Dorongan filantropi yang bersifat spontan- sebagaimana yang diungkapkan oleh Ericca Bronstein- akan memiliki keindahan tersendiri ketika memberi itu tidak dirasionalisasi dalam hal sederhananya tidak diatur, memberi akan mampu menyentuh emosi sekaligus sebagai tindakan kebebasan.

Pernanan NGO secara global telah memberikan contoh bahwa beragam organisasi yang bergerak dalam bidang Faith Bassed Organization telah memberikan implikasi terhadap wacana pembangunan. Sementara organisasi keagamaan secara historis memainkan peran penting dalam penyediaan bantuan yang bersinggungan dari konsepsi pembangunan secara historis yang bersifat sekuler. ${ }^{1}$ Latar belakang ini muncul tidak terlepas dari banyak keinginan manusia untuk memperbaiki standar hidup orang miskin yang dioperasionalkan melalui LSM sekuler dan berbasis agama. Namun ada juga FBOS (Faith Bassed Organization) yang memainkan peran utama dalam masyarakat, walaupun LSM dan FBOS memiliki perbedaan pelembagaan namun memiliki titik temu yang sama dalam wacana pembangunan.

Dalam beberapa tahun FBOS telah memberikan berbagai layanan kepada publik, seperti merawat orang lemah dan lanjut usia dan bantuan kemanusiaan lainya. Dalam hal ini FBOS memiliki setidaknya dua identitas, pertama adalah sebagai agen pengembangan dalam upaya peningatan kesejahteraan materi orang miskin, dan yang kedua adalah organisasi yang keberadaanya dikonstruksikan dari dasar iman dan pemahamanya tentang keagamaan. ${ }^{2}$ Organisasi yang bergerak di bidang kemanusiaan telah lahir atas dasar bingkai komunitas agama dalam menjalankan perananya dalam bidang pembangunan yang berada di wilayah sekuler, namun di sisi lain gerakan ini muncul untuk mengakomodir kebutuhan yang selayaknya di jalankan oleh negara atau dalam hal ini ialah pemerintah.

Di Indonesia pada masa orde baru, kebangkitan kelas menengah muslim pada 1980 an telah memberikan pengaruh terhadap ekspresi agama di ruang politik dan publik, zakat

1 Marie Juul Petersen, For Humanity or for the Umma? Aid and Islam in Transnational Muslim NGOs (London: Hurst \& Company, 2015), 18.

2 Matthew Clarke, ed., Handbook of Research on Development and Religion (Cheltenham, Glos, UK; Northampton, MA: Edward Elgar, 2013); Matthew Clarke and David Tittensor, Islam and Development: Exploring the Invisible Aid Economy (London: Routledge, 2016), 40, https://www.taylorfrancis.com/books/e/9781315589893; Rodney H. Clarken, 'Considering Moral Intelligence as Part of a Holistic Education.', Online Submission, 2010. 
misalnya telah menjadi wacana bentuk alternatif kesejahteraan sosial oleh pemerintahan pada waktu itu, pendirian BAZ (Badan Amil Zakat) yang dikelola negara untuk mengintegrasikan wacana pembangunan yang digaungkan orde baru. ${ }^{3}$ Bergeser lagi ke era reformasi juga terdapat berbagai lembaga yang bergerak di bidang kepedulian sosial baik yang NGO maupun yang berada di bawah naungan pemerintah, begitu pula dengan caracara yang berbeda di setiap lembaga donor dalam pengoperasionalanya, salah satu fakta mengemukakan bahwa setiap ormas yang berbasis agama dalam hal ini Islam misalnya, sudah memiliki wadah sendiri-sendiri dalam upaya gerakan filantropi, dan ada pula yang bukan mengatasnamakan ormas berbasis agama namun banyak diinsipirasikan oleh etika agama, salah satunya adalah gerakan filantropi "Sedekah Rombongan". Lembaga ini memiliki jargon "menyampaikan titipan langit tanpa perlu rumit, sulit dan berbelit", gerakan memberi secara spontan merupakan ciri khas dari lembaga ini, hal ini menunjukan betapa Deriddian dalam praktek memberi.

Sedekah Rombongan merupakan salah satu organisasi FBOS yang berkembang sangat pesat sejak awal berdirinya. Pada mulanya, Sedekah Rombongan merupakan organisasi jalanan yang menghimpun dana tanpa sistem organisasi yang rapi dan hanya memiliki kurang dari sepuluh anggota didalamnya. Namun seiring dengan berkembangnya organisasi ini, dalam waktu empat tahun Sedekah Rombongan menjadi salah satu organisasi sosial yang mapan dan tersebar di seluruh penjuru Indonesia dengan berpusat di Daerah Istimewa Yogyakarta.

Perjalanan Sedekah Rombongan pada tahun 2011 yang memulai pergerakan berawal dari Saptuari Sugiarto yang meggalang dana lewat media sosial kemudian menyampaikannya kepada orang-orang yang membutuhkan. Pada 2012 Sedekah Rombongan memulai sistem pendampingan berobat untuk dhuafa sakit dan membuat akta pendirian dengan nomor 03/tanggal 13 Juni 2012. Pada 2014 Sedekah Rombongan mendapatkan surat izin operasional dari kantor BKPM Daerah Istimewa Yogyakarta Nomor: 222/191/GR.I/2014 tanggal 21 Maret 2014. Pada 2016 Sedekah Rombongan mendaftarkan diri ke Kemenkumham Republik Indonesia sebagai perkumpulan supaya dapat bergerak secara nasional. Pada 2018 Sedekah Rombongan bertransformasi menjadi bagian dari Yayasan Gerakan Sedekah Rombongan (YGSR).

Visi Sedekah Rombongan adalah "menjadi organisasi sosial terpercaya di Indonesia, yang selalu bergerak membantu sesama dalam segala kondisi”. Adapun misi Sedekah Rombongan antara lain mengajak masyarakat di Indonesia untuk bersama-sama merutinkan sedekah dengan mengedukasi tentang Gerakan Sedekah Rombongan; menyampaikan dana sedekah tepat sasaran kepada dhuafa yang membutuhkan, mendampingi yang sakit tanpa prosedur yang rumit; dan melaporkan semua santunan yang sudah diberikan dengan rapi dan akuntable untuk menjaga kepercayaan masyarakat.

Sedekah Rombongan merupakan sebuah gebrakan organisasi sosial yang berawal dari Yogyakarta. Pada mulanya, organisasi ini merupakan kumpulan anak muda yang menamai

\footnotetext{
${ }^{3}$ Najib Kailani and Martin Slama, 'Accelerating Islamic Charities in Indonesia: Zakat, Sedekah and the Immediacy of Social Media', South East Asia Research, 4 December 2019, 5, https://doi.org/10.1080/0967828X.2019.1691939; Amelia Fauzia, Faith and the State: A History of Islamic Philanthropy in Indonesia, Brill's Southeast Asian Library, v. 1 (Leiden ; Boston: Brill, 2013).
} 
diri mereka sebagai "sedekah jalanan", dimana mereka tidak memiliki struktur organisasi yang jelas. Seiring dengan maraknya gerakan dan kesadaran masyarakat terhadap sedekah, maka Sedekah Rombongan tumbuh menjadi organisasi sosial yang patut diperhitungkan. Hanya dalam kurun waktu kurang dari empat tahun, organisasi ini melebarkan sayapnya di seluruh pulau Jawa dan beberapa daerah di luar pulau Jawa.

Memiliki relawan tanpa bayaran dengan jumlah tidak kurang dari 300 orang, Sedekah Rombongan tentu memiliki nilai tambah yang tidak dimiliki organisasi lain, bahkan organisasi profit sekalipun. Dengan pola rekruitmen yang profesional dan tidak main-main, komitmen para relawan tidak dapat dipandang sebelah mata. Oleh sebab itu penelitian ini akan mengungkapkan fenomena Sedekah Rombongan berdasarkan ungkapan langsung dari para relawan yang telah bergabung dalam organisasi ini untuk mendapatkan gambaran tentang komitmen relawan organisasi nirlaba Sedekah Rombongan.

Tulisan ini akan memfokuskan pada kajian terhadap organisasi gerakan amal filantropi yang berbasis faith based organization yang berorientasi pada pelayanan kemanusiaan oleh para relawan yang tergabung dalam organisasi Sedekah Rombongan di Yogyakarta. Penelitian ini menjelaskan mengenai motif dorongan gerakan para relawan dalam bekerja di organisasi amal Sedekah Rombongan, dan untuk mengetahui bagaimana kinerja yang dilakukan oleh SR baik melalui mekanisme instrumental maupun reaksional atau spontanitas dalam operasional organisasinya.

\section{Metode Penelitian}

Penelitian ini menggunakan metode penelitian kualitatif yang berusaha menghasilkan penemuan-penemuan yang tidak dicapai dengan menggunakan prosedur statistik. Penelitian ini bertujuan untuk menanyakan maupun mengetahui tentang karakteristik yang ada di balik relawan SR dan latar belakang sosialnya, kemudian dideskripsikan secara akurat untuk menemukan karakteristik dan inti permasalahan secara mendalam dan dilakukan dalam ruang lingkup organisasi sosial ini dan perlu ditekankan di sini bahwa hasil penelitian ini tidak dapat digeneralisasikan di luar komunitas atau organisasi yang diteliti. Penelitian ini merupakan penelitian lapangan (field research) dengan menekankan pada observasi dan wawancara sebagai pengumpulan data ${ }^{4}$ Sedangkan tipikal informan yang diwawancarai dipilih dengan menggunakan karakteristik gender yakni relawan perempuan dan laki-laki yang sekurang-kurangnya 6 orang informan sehingga diharapkan akan dapat mengetahui lebih lanjut tentang fakta dan motif serta karakteristik organisasi yang bergerak dalam bidang filantropi ini sehingga dapat ditarik sebuah kesimpulan yang dapat mengarah pada problematika penelitian.

Adapun metode dalam pengumpulan data di dalam penelitian ini antara lain dengan melalui observasi dan wawancara kepada para relawan SR (Sedekah Rombongan) sebanyak empat orang, yang terdiri dari dua laki-laki dan dua perempuan. Kemudian lokasi penelitian

4 John W. Creswell, Qualitative Inquiry \& Research Design: Choosing among Five Approaches, 2nd ed (Thousand Oaks: Sage Publications, 2007); Moloeng Lexy J, Metodologi penelitian Kualitatif, 29th ed. (Bandung: Rosdakarya, 2011). 
ini berada di Lokasi Yayasan Gerakan Sedekah Rombongan berada di Jl. Wonosari Km.7 Bumen Wetan RT 07 Mantup, Banguntapan, Bantul, Daerah Istimewa Yogyakarta.

\section{Hasil Penelitian}

Delapan tahun Sedekah Rombongan bergerak sebagai lembaga sosial yang berombongan menyalakan secercah harapan. Sedekah Rombongan mempunyai sarana dan prasarana untuk menunjang pergerakannya, antara lain Rumah Singgah Sedekah Rombongan (RSSR) dan Mobil Tanggap Sedekah Rombongan (MTSR). Keduannya memiliki peran penting dalam pergerakan Sedekah Rombongan. RSSR berfungsi sebagai tempat singgah atau tempat tinggal sementara bagi para pasien dhuafa untuk menunggu jadwal tindakan atau penanganan lebih lanjut dari rumah sakit tempat pasien dirujuk.

Sedekah Rombongan merupakan organisasi sosial kemanusiaan yang berada dibawah naungan Yayasan Gerakan Sedekah Rombongan yang telah terdaftar di Kementerian Hukum dan HAM Republik Indonesia dengan nomor yayasan AHU 0009592.AH.01.12. Tahun 2018. Sedekah Rombongan mempunyai program pendampingan kepada dhuafa sakit untuk berobat sampai tuntas dan menyalurkan bantuan sosial kemanusiaan lainnya yang siap disalurkan oleh relawan yang disebut dengan kurir Sedekah Rombongan.

Lokasi Yayasan Gerakan Sedekah Rombongan berada di Jl. Wonosari Km.7 Bumen Wetan RT 07 Mantup, Banguntapan, Bantul, Daerah Istimewa Yogyakarta. Relawan Sedekah Rombongan disebut sebagai kurir Sedekah Rombongan yang terus bergerak menghidupkan kembali harapan hingga ke pelosok negeri. Sejak 2011 Sedekah Rombongan telah berkhidmat membantu sesama yang membutuhkan tanpa memandang suku, agama, maupun ras. Semakin hari sedekah yang diterima semakin bertambah, sehingga bentuk khidmat yang dilakukan menjadi beragam. Awalnya hanya menyampaikan santunan berupa uang kepada dhuafa yang membutuhkan. Kemudian semakin berkembang, maka menyampaikan bantuan uang atau barang kepada dhuafa, pondok pesantren, panti asuhan, merenovasi rumah orang-orang pra-sejarah yang hampir roboh, serta mendampingi dhuafa sakit berobat ke rumah sakit.

Salah satu program yang menjadi ciri khas pergerakan Sedekah Rombongan adalah pendampingan dhuafa sakit yang dimulai pada tahun 2012. Progam pendampingan pasien dilatarbelakangi oleh masalah minimnya jumlah masyarakat kecil yang menerima jaminan kesehatan istilah lainnya BPJS atau Kartu Indonesia Sehat (KIS) yang belum ada saat itu, sehingga masyarakat kecil yang sakit dan memiliki harapan sembuh tidak bisa berobat hanya karena tidak memiliki biaya. Selain itu, bagi masyarakat kecil yang menderita penyakit serius yang memerlukan pengobatan jangka panjang. Maka Sedekah Rombongan hadir dengan program pendampingan pasien.

Adapun alur proses survei pasien sampai menjadi pasien dampingan antara lain pertama informasi dhuafa sakit dari laporan masyarakat, kedua kurir Sedekah Rombongan melakukan survei dengan mendatangi rumah dhuafa sakit, ketiga memberikan santunan yaitu Sedekah Rombongan membantu ikhtiar pengobatan dhuafa dengan support akomodasi dan transportasi, bantuan biaya pembuatan jaminan kesehatan dan bantuan dana untuk pembelian obat yang tidak ter-cover jaminan kesehatan, keempat pendampingan pasien dhuafa sakit yang mempunyai peluang kesembuhan. Hal ini ditegaskan oleh relawan 
yang bernama pak Suro berusia 33 tahun telah bergabung pada tahun 2015 akhir, beliau menyampaikan bahwa setiap organisasi harus memiliki benang merah, tata cara dan prosedur, sehingga dapat berjalan dengan lancar.

Mendampingi seseorang yang sedang sakit bukan kegiatan yang mudah, tidak sedikit waktu dan tenaga yang dikeluarkan. Bagi kurir Sedekah Rombongan bisa mendampingi pasien mulai dari awal survei, proses pengobatan, hingga dinyatakan sembuh adalah kesempatan yang luar biasa. Semua yang diinvestasikan selama proses tersebut tidak akan pernah sia-sia, walaupun yang dapat diberikan hanya berupa waktu dan tenaga. Hal ini ditegaskan oleh relawan yang bernama mbak Ratna berusia 25 tahun telah bergabung pada tahun 2014 akhir, beliau mempunyai pengalaman yang sangat berkesan saat melakukan survei untuk mencari data dari laporan masyarakat yang berlokasi sangat sulit akses menuju ke lokasi, suatu daerah yang sangat jauh dari perkotaan melewati ladang agar sampai. Mencari dhuafa sakit yang membutuhkan bantuan, sesampainya lokasi dan mendapatkan data yang telah menjadi target sehingga merasa puas atas capaiannya tersebut.

Banyak hal yang dapat diambil hikmahnya sebagai kurir Sedekah Rombongan dalam melaksanakan program, salah satunya adalah pengalaman. Sebagai kurir Sedekah Rombongan mempunyai pengalaman mendampingi pasien selama proses pengobatan menuai beragam kebaikan, antara lain berlatih memelihara amanah; berlatih komunikasi dan manajemen emosi; paham seluk beluk administrasi di rumah sakit; belajar istilah dunia kesehatan; belajar keterampialn bantuan hidup dasar; dan mendapat pelatihan orientasi umum ambulan.

Max Weber ${ }^{5}$, dalam Ekonomi dan Masyarakat membahas alasan instrumental dalam konteks aksi sosial yang lebih luas. Bagi Weber, aksi sosial adalah tindakan yang berorientasi pada perilaku orang lain. Ini jatuh ke dalam empat tipe ideal yakni rasional instrumental dengan menggunakan ekspektasi hasil sebagai kondisi dan sarana untuk mencapai tujuan yang dihitung, kedua, nilai rasional yang mengevaluasi tindakan demi kepentingannya sendiri terlepas dari kemungkinan hasil yang sukses, ketiga ialah tindakan afektif yang ditentukan oleh perasaan atau emosi; dan keempat adalah tindakan tradisional yang ditentukan oleh kebiasaan. Weber berpendapat bahwa tindakan rasional secara instrumental, ketika tujuan, sarana, dan hasil ditimbang secara rasional, tidak sesuai dengan tindakan yang bisa mempengaruhi atau tradisional. Nilai-tindakan rasional juga tidak rasional. Semakin seseorang mengarahkan tindakan menuju nilai demi kepentingannya sendiri maka semakin sedikit ia dipengaruhi oleh pertimbangan konsekuensi dari tindakannya.

Berbeda dengan konsepsi webber dalam memberi, Marcel Mauss menginterpretasikan tentang pemberian adalah sebuah transaksional yang mebutuhkan hubungna timbal balik dan pengembalian, jadi tindakan pemberian sebenarnya ialah juga merupakan tidak sepenuhnya tindakan yang tulus dalam meberi namun ada motif pengembalian. Konspe Mauss berbeda lagi dengan Derrida bahwa semestinya pemberian tidak boleh terikat dan diatur yang memiliki nilai keadilan yang distributive yang ekonomis dan simbolis bukan sebagai pertukaran bahkan sirkulasi kontraktual. Pemberian atas

\footnotetext{
${ }^{5}$ Max Weber, Economy and Society: An Outline of Interpretive Sociology (University of California Press, 1978).
} 
dorongan hati menentang apa yang diberikan pertanggungjawaban melalui tindakan instrumental. Fokus pada efek atau, bisa dikatakan hasil dari memberi adalah upaya untuk memerintah dalam dorongan untuk memberi. Pemberian impulsif kepada pengemis biasanya tidak ditempatkan dalam kategori yang sama dengan pemberian kepada lembagalembaga seperti LSM, terlepas dari kenyataan bahwa kedua bentuk sumbangan merespons penderitaan manusia.

Organisasi amal seperti SR ini juga menyerukan tindakan pengorbanan, baik dalam bentuk sumbangan moneter atau kerja sukarela. Mereka sebagian besar mengandalkan zakat, sedekah wajib, dan sedekah, sumbangan sukarela. Secara resmi, Sedekah Rombongan (SR) bukanlah organisasi keagamaan namun hampir semua relawan adalah muslim dan sekaligus mempraktekan cara kerja muslim dan menggunakan retorika agama ketika menjelaskan cara kerja relawanya. Mereka umumnya memiliki motivasi kuat untuk ikut gabung dalam anggota relawan dengan terinspirasi oleh etos agama, yakni menjadi manusia bermanfaat untuk orang lain, mendapat pahala, mendapat ridlo Allah dan juga termasuk didorong oleh kepentingan sosialnya yakni ada timbal balik yang mereka yakini ketika membantu meringankan beban orang lain maka akan ringan pula beban dirinya dan hidupnya. Hal demikian yang menjadi dorongan mereka untuk ikut serta dalam relawan SR.

Organisasi SR ini juga telah masuk dalam struktur rasional instrumental, walaupun dulunya merupakan aksi jalanan secara spontan namun sekarang dengan berkembang pesatnya gerakan ini dan telah memiliki berbagai cabang diseluruh Indonesia maka perlu penataan secara administratif dan melalui jalur prosedural yang dikehendaki negara. Artinya pengakuan dari pemerintah perlu dibutuhkan oleh SR agar mendapatakan perlindungan dan sekaligus kebebasan dalam menyalurkan bantuan kemanusiaanya. Memberi sedekah adalah aspek dari setiap agama dalam Islam itu adalah salah satu dari lima rukun iman; dalam agama Hindu, Buddha, Konghucu, dan Kristen awal dan Yudaisme itu dianggap pekerjaan yang baik. Sehubungan dengan itu, dalam semua agama-agama ini, mengejar impersonal dan ekonomis rasional kekayaan dianggap etis irasional, sering mencela sebagai keserakahan. Meskipun ada ruang untuk sentimen amal dalam hubungan antara orangorang, tidak ada kemungkinan hubungan antara mereka yang didefinisikan oleh hubungan ekonomi instrumental murni seperti petugas pinjaman bank dan tukang kredit. ${ }^{6}$ Bagi Weber, dunia yang secara rasional rasional dari aktivitas ekonomi murni menentang amal.

\section{Penutup}

Dalam praktek Filantropi yang dilakukan oleh SR Sedekah Rombongan merupakan bagian dari dinamika lembaga donatur yang berupaya menciptakan ruang bagi kaum dhuafa untuk mendapatkan pesan dari langit melalui mekanisme yang tidak rumit dan sulit. Sedekah Rombongan berupaya mendobrak kebiasaan lembaga-lembaga donatur yang bergerak dan berkerja secara rasional instrumental yang berpatokan pada hasil dan parameter yang rumit, meskipun lembaga ini tunduk pada regulasi negara namun gerakan memberi secara spontan tetap dilakukan tanpa memandang basis agama maupun latar belakang sosial yang membutuhkan. Sedekah Rombongan merupakan salah satu contoh

${ }^{6}$ Erica Bornstein, 'The Impulse of Philanthropy', Cultural Anthropology 24, no. 4 (2009): 623, https://doi.org/10.1111/j.1548-1360.2009.01042.x. 
organisasi nirlaba yang berkembang sangat pesat sejak awal berdirinya. Pada mulanya, Sedekah Rombongan yang dulunya merupakan organisasi jalanan yang menghimpun dana tanpa sistem organisasi yang rapi dan hanya memiliki kurang dari sepuluh anggota di dalamnya. Namun sekarang seiring dengan berkembangnya organisasi ini, dalam waktu empat tahun Sedekah Rombongan menjadi salah satu organisasi sosial yang memiliki banyak relawan muslim serta memiliki retorika agama yang kuat dan juga memiliki etos agama yang diinsiprasikan oleh para relawan, hingga saat ini organisasi SR telah mapan dan masuk dalam struktur regulasi negara tanpa meninggalkan prinsipnya dan komitmenya yakni untuk menyampaikan pesan dari langit tanpa sulit, dan rumit.

\section{Referensi}

Bornstein, Erica. 'The Impulse of Philanthropy'. Cultural Anthropology 24, no. 4 (2009): 622-51. https://doi.org/10.1111/j.1548-1360.2009.01042.x.

Clarke, Matthew, ed. Handbook of Research on Development and Religion. Cheltenham, Glos, UK ; Northampton, MA: Edward Elgar, 2013.

Clarke, Matthew, and David Tittensor. Islam and Development: Exploring the Invisible Aid Economy. London: Routledge, 2016. https://www.taylorfrancis.com/books/e/9781315589893.

Clarken, Rodney H. 'Considering Moral Intelligence as Part of a Holistic Education.' Online Submission, 2010.

Creswell, John W. Qualitative Inquiry \& Research Design: Choosing among Five Approaches. 2nd ed. Thousand Oaks: Sage Publications, 2007.

Fauzia, Amelia. Faith and the State: A History of Islamic Philanthropy in Indonesia. Brill's Southeast Asian Library, v. 1. Leiden ; Boston: Brill, 2013.

Kailani, Najib, and Martin Slama. 'Accelerating Islamic Charities in Indonesia: Zakat, Sedekah and the Immediacy of Social Media'. South East Asia Research, 4 December 2019, 1-17. https:// doi.org/10.1080/0967828X.2019.1691939.

Lexy J, Moloeng. Metodologi penelitian Kualitatif. 29th ed. Bandung: Rosdakarya, 2011.

Petersen, Marie Juul. For Humanity or for the Umma? Aid and Islam in Transnational Muslim NGOs. London: Hurst \& Company, 2015.

Weber, Max. Economy and Society: An Outline of Interpretive Sociology. University of California Press, 1978. 